\title{
Exposure as Collected Reference Identifier
}

National Cancer Institute

\section{Source}

National Cancer Institute. Exposure as Collected Reference Identifier. NCI Thesaurus.

Code C117469.

A sequence of characters used to identify, name, or characterize the collected exposure reference. 